\title{
Changes in Apoptosis-related Gene Expression Induced by Repression of FGFR1 by RNA Interference in Embryonic Fibroblasts and Cancerous Cells from Chicken
}

\author{
Sang In Lee, Bo Ram Lee, Young Sun Hwang, Deivendran Rengaraj and Jae Yong Han* \\ WCU Biomodulation Major, Department of Agricultural Biotechnology, Seoul National University, 599 Gwanak-ro, \\ Gwanak-gu, Seoul 151-921, Korea
}

\begin{abstract}
Fibroblast growth factor receptor 1(FGFR1) plays roles in angiogenesis, wound healing, and embryonic development via the regulation of cell proliferation, differentiation, and survival. It is well known that ectopic expression of FGFR1 is associated with cancer development. To characterize the function of FGFR1 in the normal and cancer cell lines DF-1 and DT40, respectively, we performed FGFR1 knockdown by RNA interference. In the DT40 cells, FGFR1 knockdown induced upregulation of FGFR2 and FGFR3 expression, downregulation of pro-apoptosis-related genes, and upregulation of anti-apoptosis-related genes. However, in DF-1 cells, FGFR1 knockdown induced upregulation of pro-apoptosis-related genes and downregulation of anti-apoptosis-related genes. Our data suggest that repression of FGFR1 induced upregulation of other FGF receptors and anti-apoptosis-related genes in cancer cells and pro-apoptosis-related genes in normal cells.
\end{abstract}

(Key words : RNA interference, FGFR1, Apoptosis, DT40, DF1)

\section{INTRODUCTION}

Fibroblast growth factors (FGFs) were discovered as mitogens for cultured fibroblasts (Gospodarowicz, 1974). A total of 22 FGFs have been identified in various organisms (Ornitz \& Itoh, 2001). FGFs induce cellular responses by binding to a family of FGF receptors (FGFRs), which are receptor tyrosine kinases (Jaye et al, 1992). FGFRs are involved in numerous biological processes during embryo development and homeostasis. FGFR1 in particular is expressed during the development of the brain in the chick, mouse, and frog (Amaya et al, 1991; Yamaguchi et al, 1994). Also, FGFR1 promotes proliferation and survival via activation of the mitogen-activated protein kinase pathway in different cell lines (Tomlinson et al, 2009).

The DT40 cell line, a B-cell lymphoma line, was permanently transformed with an avian leukosis virus to cause immunoglobulin gene conversion (Baba et al, 1985; Buerstedde et al, 1990). The DT40 cell line exhibits a high frequency of recombination and thus is often used as a model system for functional gene studies (Hudson et al, 2002; Johnson et al, 2009). The DF-1 cell line, a line of immortalized chicken embryonic fibroblasts, is susceptible to transformation by numerous oncogenes and efficiently replicates avian retroviruses (Himly et al, 1998). Small interfering RNA (siRNA) complementary to a target mRNA sequence in a cell can be used to downregulate target gene expression, making the RNA interference (RNAi) technique applicable in functional genomic studies. The RNAi technique has been used to study gene function related to somitogenesis and retinal development in early stages of chicken embryos in ovo (Harpavat \& Cepko, 2006).

To investigate the function of FGFR1 in different cell types, we designed a short hairpin RNA (shRNA) for FGFR1 knockdown and compared gene expression patterns between normal DF-1 cells and DT40 cancer cells. Our results indicate that FGFR1 silencing by RNA interference induced the upregulation of anti-apoptosis-related genes and other FGFRs in cancer cells, whereas pro-apoptosis-related genes were upregulated in normal fibroblasts.

\footnotetext{
* Corresponding author: Jae Yong Han, Ph.D., Seoul National University 599 Gwanak-ro, Gwanak-gu, Seoul 151-921, Korea. Tel: +82-2-880-4810, Fax: +82-2-874-4811, E-mail: jaehan@snu.ac.kr
} 


\section{MATERIALS AND METHODS}

1. Design of target-specific shRNA and RNA interference vector construction

Based on the full-length FGFR1 sequence, FGFR1-specific siRNAs were designed using siRNA Target Finder (http: //www.ambion.com/techlib/misc/siRNA/finder.html). Candidate siRNA sequences were analyzed using the pSilencer $^{\mathrm{TM}}$ Expression Vector Insert Design Tool for shRNA (Ambion, Austin, TX; http://www.ambion.com/techlib/misc/psilencer_converter. html), to generate the loop sequence (TTCAAGAGA) required for making a hairpin structure. The designed shRNAs were cloned into the BamHI and HindIII sites in pSilencer expression vector (Ambion).

\section{Cell culture and transfection}

The procedures for animal management, reproduction, and embryo manipulation followed standard operating protocols used in our laboratory. Cell culture and transfection were performed according to our previous report (Lee et al, 2010). The chicken cell lines DT40 and DF-1 were purchased from ATCC (Global Bioresource Center). DT40 and DF-1 cells were grown in Dulbecco's modified Eagle's medium (DMEM, High glucose; Gibco, Grand Island, NY) containing $10 \%$ fetal bovine serum (Hyclone, Logan, UT), and $1 \%$ antibiotic-antimycotic solution (Gibco) at $37^{\circ} \mathrm{C}$ in $5 \% \mathrm{CO}_{2}$ at $90 \%$ humidity. For transfection, DT40 or DF-1 cells were resuspended at $1 \times 10^{6}$ cells per $100 \mu$ l of Nucleofection-V solution (Lonza, Basel, Switzerland). DNA was added to the cell solution, and nucleofection was performed using the A-033 program (Lonza). Then, $500 \mu$ of medium were added to each cell solution, and the cells were transferred to a 35-mm culture dish and cultured for $48 \mathrm{~h}$, with daily changes of the medium.

\section{Quantitative real-time PCR}

RNA extraction, cDNA synthesis, and quantitative real-time PCR analysis were performed according to our previous reports (Lee et al, 2007; Lee et al, 2009). To estimate the expression and effect of gene silencing, total RNA was extracted from the cultured cells. Total RNA $(1 \mu \mathrm{g})$ from each sample was used to create single-stranded cDNA, using a Superscript III first-strand synthesis system (Invitrogen).
Sequence-specific primers were designed using the Primer3 program (http://frodo.wi.mit.edu/). Real-time PCR was performed using an iCycler iQ real-time PCR detection system (Bio-Rad Laboratories, Hercules, CA) and SYBR Green1 (Sigma, St. Louis, MO). Wells without cDNA were included as negative controls. Each test sample was run in triplicate. The PCR conditions were $94^{\circ} \mathrm{C}$ for 3 min, followed by 40 cycles of $94^{\circ} \mathrm{C}$ for $30 \mathrm{~s}, 59$ to $61^{\circ} \mathrm{C}$ for $30 \mathrm{~s}$, and $72^{\circ} \mathrm{C}$ for $30 \mathrm{~s}$, using a melting curve program (temperature increase from 55 to $95^{\circ} \mathrm{C}$ at a rate of $0.5^{\circ} \mathrm{C} / 10 \mathrm{~s}$ ) and continuous fluorescence monitoring. The results are reported as the relative expression after normalization of the transcript to the level of glyceraldehyde 3-phosphate dehydrogenase (GAPDH) as an endogenous control, with the nonspecific control as a calibrator, using the $2^{-\Delta \Delta \mathrm{Ct}}$ method (Livak \& Schmittgen, 2001).

\section{Statistical analysis}

Student's t-test and analysis of variance (ANOVA) were performed to compare the effect of FGFR1 knockdown in both cell lines. SAS software (SAS Institute, Cary, NC) was used for the calculations. A P-value $<0.05$ was considered to indicate statistical significance.

\section{RESULTS}

\section{Repression of FGFR1 expression by RNA inter- ference in DT40 and DF-1 cells}

To obtain FGFR1-specific shRNA, we designed two shRNA sequences that obeyed Thuthel's rule (http://www. ambion.com/techlib/misc/siRNA/finder.html). The target sequences were located at 401 and 2,561 bp, respectively, in the FGFR1 mRNA sequence (Table 1). To confirm that the two shRNAs repressed the expression of FGFR1 mRNA, expression vectors containing the shRNAs were introduced into DT40 and DF-1 cells by nucleofection, a modified electroporation technique. Nonspecific shRNA containing no complementary sequence in the chicken genome was used as a control.

The FGFR1 mRNA expression levels were analyzed $48 \mathrm{~h}$ after nucleofection. The shRNA_401 vector produced 56 $\pm 9 \%$ $(\mathrm{P}<0.0001)$ repression of FGFR1 mRNA expression in DT40 cells (Fig. 1A) and $54 \pm 3 \%(\mathrm{P}<0.0001)$ repression in $\mathrm{DF}-1$ cells (Fig. 1B) compared with expression in the controls. The 
Table 1. List of synthesized candidate shRNAs for FGFR1 specific knockdown

\begin{tabular}{|c|c|c|c|c|}
\hline Candidate shRNA & Target Sequence & Direction & Designed shRNA Sequence (5'-3') & Location* \\
\hline shRNA_FGFR1_401 & $\begin{array}{l}\text { AACGTCTCAGACGCA } \\
\text { СТCCCT }\end{array}$ & $\begin{array}{l}\text { Forward } \\
\text { Reverse }\end{array}$ & $\begin{array}{l}\text { GATCCGCGTCTCAGACGCACTCCCTTTCAAGAGAAGGG } \\
\text { AGTGCGTCTGAGACGTTTTTTGGAAA } \\
\text { AGCTTTTCCAAAAAACGTCTCAGACGCACTCCСTTCTCT } \\
\text { TGAAAGGGAGTGCGTCTGAGACGCG }\end{array}$ & 401 \\
\hline shRNA_FGF1_2561 & $\begin{array}{l}\text { AACTGCCAAAGCTTT } \\
\text { CGGCT }\end{array}$ & $\begin{array}{l}\text { Forward } \\
\text { Reverse }\end{array}$ & $\begin{array}{l}\text { GATCCGCTGCCCAAAGCTTTCGGCTTTCAAGAGAAGCC } \\
\text { GAAAGCTTTGGGCAGTTTTTTGGAAA } \\
\text { AGCTTTTCCAAAAAACTGCCCAAAGCTTTCGGCTTCTCT } \\
\text { TGAAAGCCGAAAGCTTTGGGCAGCG }\end{array}$ & 2561 \\
\hline Nonspecific shRNA $^{\#}$ & $\begin{array}{l}\text { GTCAGGCTATCGCGT } \\
\text { ATCG }\end{array}$ & Forward & $\begin{array}{l}\text { GATCCGTCAGGCTATCGCGTATCGTTCAAGAGACGATA } \\
\text { CGCGATAGCCTGACTTTTTTGGAAA } \\
\text { AGCTTTTCCAAAAAAGTCAGGCTATCGCGTATCGTCT } \\
\text { CTTGAACGATACGCGATAGCCTGACG }\end{array}$ & N/A \\
\hline
\end{tabular}

\footnotetext{
\# Nonspecific shRNA has no complementary sequence in the chicken genome and was used as a gene silencing control.

* Location refers to the first nucleotide of the target sequence in FGFR1 mRNA sequence.
}

introduction of pMax_GFP vector (Lonza), used to determine the transfection efficiency of nucleofection, revealed transfection efficiencies of $63 \pm 6 \%(\mathrm{P}<0.01)$ and $60 \pm 6 \%(\mathrm{P}<0.01)$ in DT40 and DF-1 cells, respectively (data not shown). We used the shRNA_401 vector for further experiments and analysis in both cell lines.

2. Effect of FGFR1 repression on the expression pattern of FGFRs in DT40 and DF-1 cells
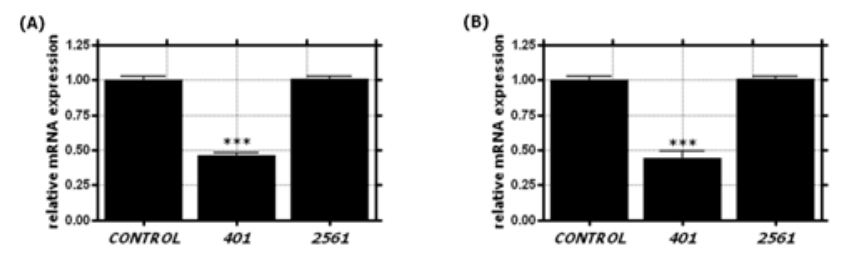

Fig. 1. Repression of FGFR1 expression by targetspecific shRNA in DT40 and DF-1 cell lines. Selected shRNA expression constructs were introduced into DT40 (A) and DF-1 (B) cells by nucleofection. Nonspecific shRNA, with no complementary sequence in the chicken genome, was used as the control. 401, shRNA_FGFR1_401 expression construct; 2561, shRNA_FGFR1_2561 expression construct; DT40, B-cell Tymphoma cell line; DF-1, immortalized chicken embryonic fibroblast cell line. Quantitative real-time PCR analysis was conducted to measure relative expression normalized to GAPDH expression. All reactions were performed in triplicate. ${ }^{* * *} \mathrm{P}<0.001$ (one-way ANOVA) compared with nonspecific shRNA. Error bars indicate the SE of triplicate analyses.
To examine the effect of repressed FGFR1 on the expression pattern of FGFRs, we performed quantitative realtime PCR analysis in the DT40 and DF-1 cell lines. In the absence of shRNA_401, both cell lines showed stronger (A)

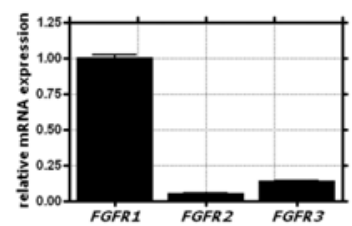

(B)

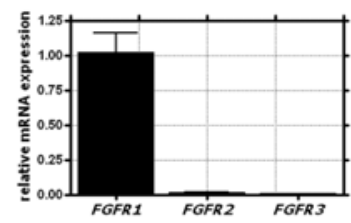

(c)

(D)
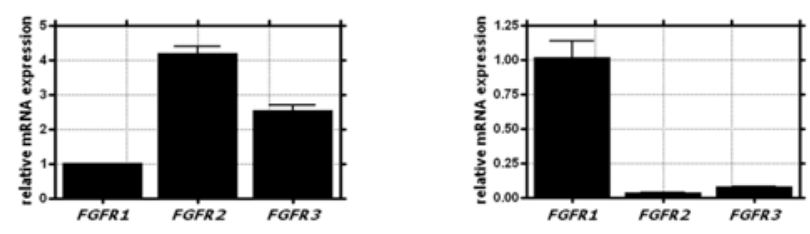

Fig. 2. Expression patterns of FGFRs in DT40 and DF-1 cell lines. (A) Relative mRNA expression of FGFRs in DT40 (B-cell lymphoma) cells, determined by quantitative real-time PCR. GAPDH was used as an endogenous control. (B) Relative mRNA expression of FGFRs in DF-1 (fibroblast) cells, determined by quantitative real-time PCR. (C) Changes in expression of FGFRs at $48 \mathrm{~h}$ after repression of FGFR1 expression in DT40 cells. (D) Changes in expression of FGFRs at $48 \mathrm{~h}$ after repression of FGFR1 expression in DF-1 cell. All reactions were performed in triplicate and normalized to $G A P D H$ expression. Error bars indicate the SE of triplicate analyses. 
Table 2. List of candidate genes by FGFR1 knockdown and primer sequences for quantitative RT-PCR

\begin{tabular}{|c|c|c|c|c|c|c|c|c|}
\hline \multirow{3}{*}{ Symbol } & \multirow{3}{*}{ Description } & \multirow{3}{*}{$\begin{array}{l}\text { Gene bank } \\
\text { No. }\end{array}$} & \multicolumn{4}{|c|}{ Relative fold change using real_time quantitative PCR } & \multirow{2}{*}{\multicolumn{2}{|c|}{ Primer }} \\
\hline & & & \multicolumn{2}{|c|}{ DT40 } & \multicolumn{2}{|r|}{ DF1 } & & \\
\hline & & & CONTROL & $\begin{array}{c}\text { FGFR1 } \\
\text { KNOCKDOWN }\end{array}$ & CONTROL & $\begin{array}{c}\text { FGFR1 } \\
\text { KNOCKDOWN } \\
\end{array}$ & Forward (5'->3') & Reverse (5'->3') \\
\hline$F A D D$ & $\begin{array}{l}\text { FRSF6)-associated } \\
\text { domain }\end{array}$ & $\mathrm{d} x$ & $1.13 \pm 0.17$ & $0.58 \pm 0.15^{* *}$ & $1.01 \pm 0.20$ & $2.96 \pm 0.12^{* * *}$ & $\begin{array}{l}\text { GGTCCAACCACC } \\
\text { CTGCTGAA }\end{array}$ & $\begin{array}{l}\text { CGCAGGTGACAGAGC } \\
\text { ATTGG }\end{array}$ \\
\hline D & $\begin{array}{l}\text { TNFRSF1A-associated via } \\
\text { death domain }\end{array}$ & XM_41 & .17 & $0.53 \pm$ & 1. & $1.32 \pm 0.11^{*}$ & $\begin{array}{l}\text { AGCCTG } \\
\text { TG }\end{array}$ & $\begin{array}{l}\text { GTGACCTGTGGGGAA } \\
\text { AGGGA }\end{array}$ \\
\hline CASP8 & $\begin{array}{l}\text { Caspase } 8 \text {, apoptosis- } \\
\text { related cysteine peptidase }\end{array}$ & NM_204592 & $1.17 \pm 0.31$ & $0.73 \pm 0.08^{* *}$ & $1.05 \pm 0.13$ & $2.24 \pm 0.16^{* *}$ & $\begin{array}{l}\text { CTGGA } \\
\text { A }\end{array}$ & $\overline{\mathrm{CCCACC}}$ \\
\hline$B I D$ & $\begin{array}{l}\text { BH3 interacting domain } \\
\text { death agonist }\end{array}$ & NM_2 & 1. & $1.11 \pm 0.10$ & (bi & $2.03 \pm 0.13^{* * *}$ & $\begin{array}{l}\text { CTTTGCTTTCCTG } \\
\text { GCGGAGT }\end{array}$ & $\begin{array}{l}\text { CCACTTCGATTCCCAT } \\
\text { CGGT }\end{array}$ \\
\hline BCL2 & B-cell CLL/lymphoma 2 & NM_205339 & $1.07 \pm 0.13$ & $1.79 \pm 0.05 *$ & $0.95 \pm 0.08$ & $0.79 \pm 0.06$ & $\begin{array}{l}\text { CTTTATCCTCCTG } \\
\text { CCССTCG }\end{array}$ & $\begin{array}{l}\text { TTCTTCCGCTTCGTCA } \\
\text { GCAA }\end{array}$ \\
\hline$B C L 2 L 1$ & $\mathrm{BC}$ & NM_001025304 & $1.09 \pm 0.22$ & $1.24 \pm 0.19$ & $1.00 \pm 0.04$ & $0.91 \pm 0.13$ & $\begin{array}{l}\text { TTCAGCGACCTC } \\
\text { ACCTCCCA }\end{array}$ & $\begin{array}{l}\text { GCCCCCAGTTCACAC } \\
\text { CATCA }\end{array}$ \\
\hline YCS & somatic & $\mathrm{N}$ & 1. & 0. & 1. & $2.19 \pm 0.17^{* *}$ & $\begin{array}{l}\text { CCAGAAATGTTC } \\
\text { CCAGTGCCA }\end{array}$ & $\begin{array}{l}\text { GAGAAGCCCTCAGCT } \\
\text { TGTCCTG }\end{array}$ \\
\hline CASP3 & $\begin{array}{l}\text { Caspase } 3 \text {, apoptosis- } \\
\text { related cysteine peptidase }\end{array}$ & NM_204725 & $1.08 \pm 0.30$ & $0.15 \pm 0.12 * * *$ & $1.03 \pm 0.07$ & $1.88 \pm 0.17^{* *}$ & $\begin{array}{l}\text { TTCAGGCACGGA } \\
\text { TGCAGATG }\end{array}$ & $\begin{array}{l}\text { CGCCATGGCTTAGCA } \\
\text { ACACA }\end{array}$ \\
\hline ASP9 & $\begin{array}{l}\text { Caspase } 9 \text {, apoptosis- } \\
\text { related cysteine peptidase }\end{array}$ & NM_424580 & $1.09 \pm 0.10$ & $0.62 \pm 0$. & 24 & $1.46 \pm 0.08 *$ & $\begin{array}{l}\text { TGACCTGGCTGA } \\
\text { CATGCTGG }\end{array}$ & $\begin{array}{l}\text { ATGGACAAGCGTTCC } \\
\text { GCAGT }\end{array}$ \\
\hline
\end{tabular}

$* \mathrm{p}<0.05$ (t-test): significant difference compared to nonspecific shRNA as a control.

$* * \mathrm{p}<0.005$ (t-test): significant difference compared to nonspecific shRNA as a control.

*** $\mathrm{p}<0.001$ (t-test): significant difference compared to nonspecific shRNA as a control.

\section{Pro-Apotosis}
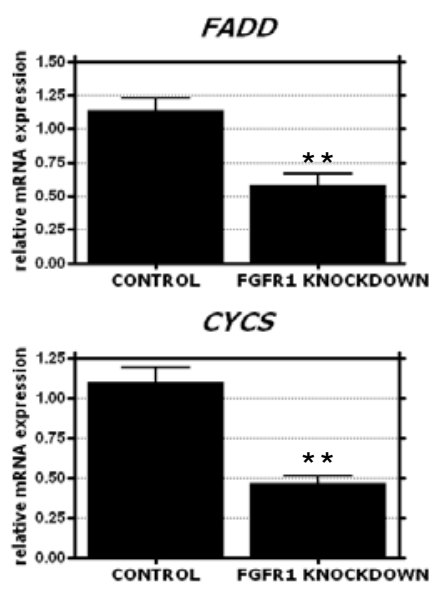

\section{Pro-Apotosis}

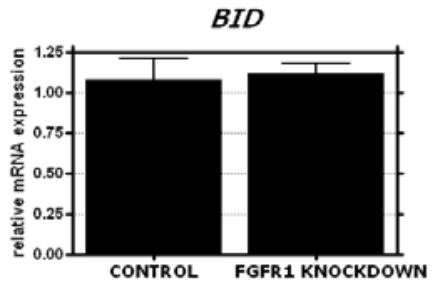

TRADD

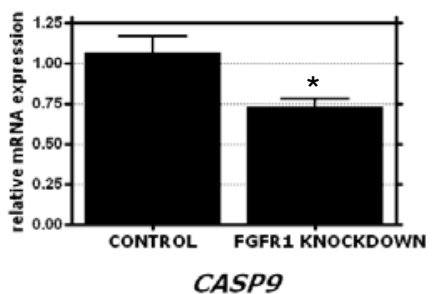

CASPS

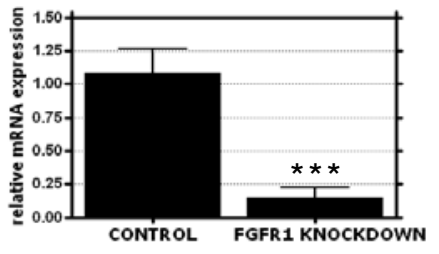

Anti-Apotosis

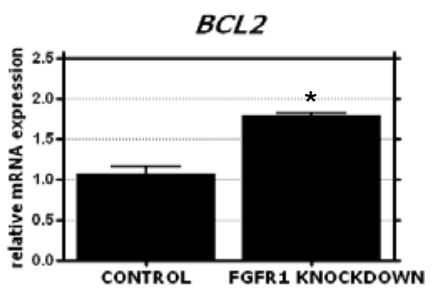

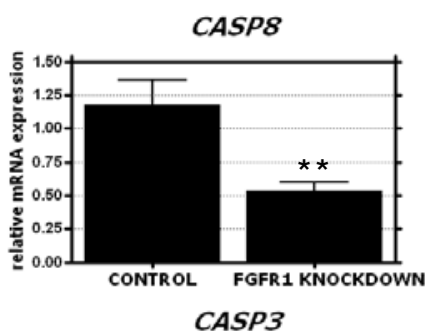

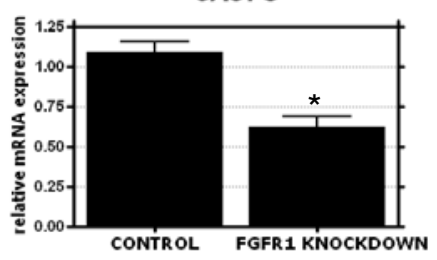

CONTROL FGFR1 KNOCKDOWN

Fig. 3. Effect of FGFR1 repression on apoptosis-related gene expression in DT40 cells. Changes in expression of apoptosis-related genes were determined by quantitative real-time PCR at $48 \mathrm{~h}$ after FGFR1 repression. Each value was divided by the value of the nonspecific control. All reactions were performed in triplicate and normalized to GAPDH mRNA expression. *** $\mathrm{P}<0.0005, * * \mathrm{P}<0.005$, and $* \mathrm{P}<0.05$ (t-test) compared with nonspecific shRNA. Error bars indicate the SE of triplicate analyses. 
expression of FGFR1 compared with FGFR2 and FGFR3 (Fig. 2A and 2B). In the presence of shRNA_401, FGFR1 knockdown altered the expression pattern of FGFRs in DT40 cells; the expression of FGFR2 and FGFR3 was highly upregulated compared with FGFR1 expression (Fig. 2C). In contrast, FGFR1 knockdown did not alter the expression of FGFRs in DF-1 cells (Fig. 2D).

3. Effect of FGFR1 repression on the expression of apoptosis-related genes in DT40 cells

The expression of apoptosis-related genes in control and FGFR1-knockdown DT40 cells was analyzed by quantitative real-time PCR (Fig. 3 and Table 2). The expression of two signal molecules that act up-stream in the apoptosis signal pathway, FADD [Fas (TNFRSF6)-associated via death domain] and TRADD (TNFRSF1A-associated via death domain), was downregulated in FGFR1-knockdown cells compared with expression in control cells. The downregulation of FADD and TRADD expression was associated with downregulated expression of CASP8, CYCS, CASP9, and CASP3, but not $B I D$, in response to FGFR1 repression. Concomitantly, expression of the anti-apoptosis signal gene BCL2 was upregulated in FGFR1-knockdown cells, although BCL2L1 expression was unchanged.

4. Effect of FGFR1 repression on the expression of apoptosis-related genes in DF-1 cells

To investigate the effect of FGFR1 repression on the expression of apoptosis-related genes in DF-1 cells, we performed quantitative real-time PCR (Fig. 4 and Table 2). In

\section{Pro-Apotosis}
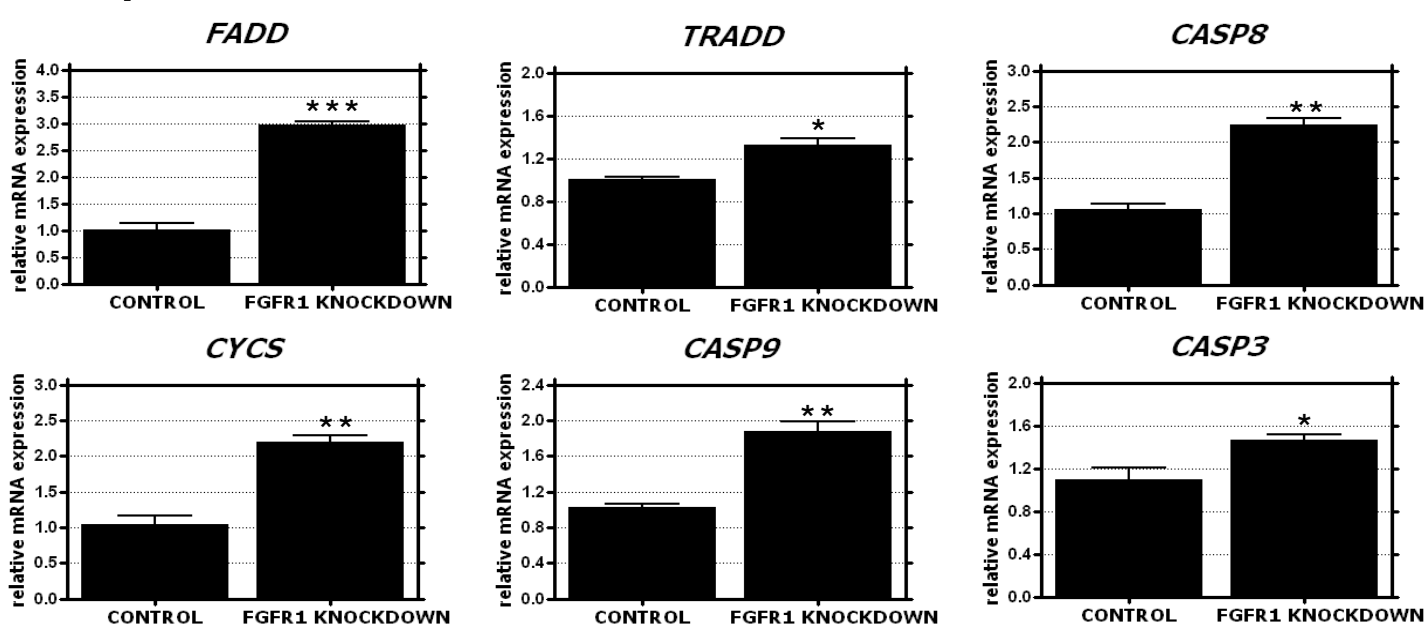

\section{Pro-Apotosis}

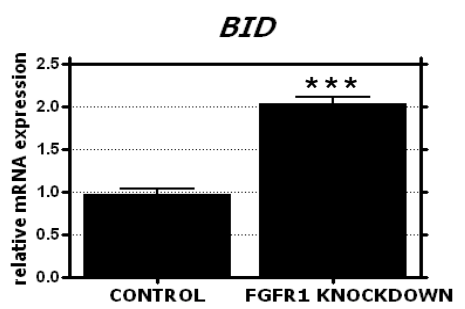

\section{Anti-Apotosis}

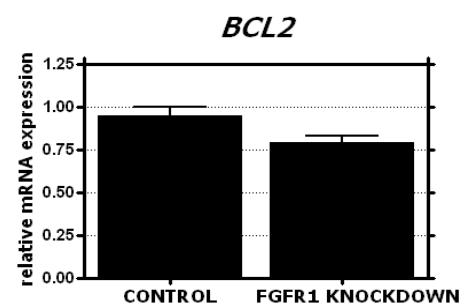

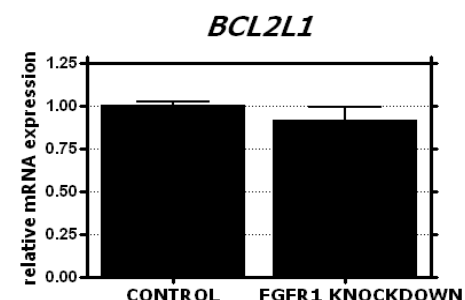

Fig. 4. Effect of FGFR1 repression on apoptosis-related gene expression in DF-1 cells. line by quantitative real-time PCR. Changes in expression of apoptosis-related genes were determined by quantitative real-time PCR at $48 \mathrm{~h}$ after FGFR1 repression. Each value was divided by the value of the nonspecific control. All reactions were performed in triplicate and normalized to GAPDH mRNA expression. *** $\mathrm{P}<0.0005, * * \mathrm{P}<0.005$, and $* \mathrm{P}<0.05$ (t-test) compared with nonspecific shRNA. Error bars indicate the SE of triplicate analyses. 
contrast to the results in DT40 cells, the expression of $F A D D$ and TRADD, and subsequently the expression of CASP8, CYCS, CASP9, CASP3, and BID were upregulated by the knockdown of FGFR1 expression in DF-1 cells. The expression of the anti-apoptosis signal genes BCL2 and BCL2L1 was not changed by FGFR1 repression in DF-1 cells.

\section{DISCUSSION}

Fibroblast growth factors (FGFs) function as mitogens in cultured cells such as somatic fibroblasts, germ cells, and blastodermal cells, and play regulatory roles during angiogenesis, wound healing, and various stages of embryonic development (Jung et al, 2005; Lee et al, 2010; Park \& Han, 2000). The binding and activation of four FGFRs (FGFR1 to -4) as well as binding to heparin or heparin sulfate proteoglycans mediate the actions of FGFs. The FGFRs have an extracellular ligand-binding site composed of three extracellular immunoglobulin-type domains (D1, D2, and D3), and FGFs interact with the D2 and D3 domains. Numerous functional studies have shown that abnormal regulation of FGFs and their receptors is associated with cancer. In particular, overexpression of FGFR1 has been observed in breast cancers (Adnane et al, 1991; Penaultllorca et al, 1995) and the upregulation of FGFs and FGFR1 has also been reported in other cancers (Yamaguchi et al, 1994; Yayon et al, 1997).

In chicken, FGFR1 is expressed during mesoderm induction and is ubiquitously expressed during brain development. The present study shows that both DT40 and DF-1 cell lines express FGFR1, as well as low levels of FGFR2 and FGFR3. The repression of FGFR1 expression induced the upregulation of FGFR2 and FGFR3 in DT40, but not DF-1 cells, suggesting that the function of FGFR1 may be different in each cell type. The DT40 cell line is a B-cell lymphoma cell line, whereas the DF-1 cell line is an immortalized fibroblast cell line. In normal fibroblasts, FGFR1 knockdown may activate apoptosis signaling by inducing the upregulation of pro-apoptosis-related genes such as FADD, TRADD, CASP8, BID, CYCS, CASP9, and CASP3. In cancer cells, FGFR1 knockdown induced the upregulation of FGFR2 and FGFR3, downregulation of pro-apoptosisrelated genes, and upregulation of the anti-apoptosis-related gene BCL2. This result imply that cancer cells and normal cells exhibit different mechanisms of cell survival. Jang (2005) reported that the reciprocal relationship between
FGFR1 and FGFR3 in colorectal tissueplays a critical role in the progression of the carcinomas to malignancy; when FGFR1 expression was repressed by FGFR1 siRNA, FGFR3 expression was effectively elevated (Jang, 2005).

These previous reports and the present results suggest that when cancer cell survival is threatened, as by the repression of FGFR1, the expression of anti-apoptosis-related genes as well as FGFR2 and FGFR3 may be induced; this response is in contrast to the induction of pro-apoptosis-related signals upon FGFR1 repression in normal fibroblasts.

We demonstrated differential expression patterns of FGFRs in cancer cells versus normal fibroblasts, using RNA interference. In normal fibroblasts, FGFR1 repression induced apoptosis through the upregulation of pro-apoptosis-related genes. However, when FGFR1 was repressed in cancer cells, the expression of FGFR2, FGFR3, and anti-apoptosis-related genes was upregulated, thereby maintaining cancer cell survival. Further investigations of the phenotypic changes induced by FGFR1 knockdown in other cancer cell types will provide new insight into cancer development and FGFR1 functions.

\section{ACKNOWLEDGEMENTS}

This work was supported by a grant from the BioGreen 21 Program (No. 20070401034010) and by the World Class University program(R31-10056) through the National Research Foundation of Korea funded by the Ministry of Education, Science, and Technology.

\section{REFERENCES}

Adnane, J., Gaudray, P., Dionne, CA., Crumley, G., Jaye, M., Schlessinger, J., Jeanteur, P., Birnbaum, D. and Theillet, C. 1991. BEK and FLG, two receptors to members of the FGF family, are amplified in subsets of human breast cancers. Oncogene 6:659-663.

Amaya, E., Musci, TJ. and Kirschner, MW. 1991. Expression of a dominant negative mutant of the FGF receptor disrupts mesoderm formation in Xenopus embryos. Cell 66:257-270.

Baba, TW., Giroir, BP. and Humphries, EH. 1985. Cell lines derived from avian lymphomas exhibit two distinct phenotypes. Virology 144:139-151.

Buerstedde, JM., Reynaud, CA., Humphries, EH., Olson, W., Ewert, DL. and Weill, JC. 1990. Light Chain Gene Conversion Continues at High-Rate in an Alv-Induced Cell- 
Line. Embo Journal 9:921-927.

Gospodarowicz, D. 1974. Localisation of a fibroblast growth factor and its effect alone and with hydrocortisone on 3T3 cell growth. Nature 249:123-127.

Harpavat, S. and Cepko, CL. 2006. RCAS-RNAi: A loss-offunction method for the developing chick retina. Bmc Developmental Biology 6: -

Himly, M., Foster, DN., Bottoli, I., Iacovoni, JS. and Vogt, PK. 1998. The DF-1 chicken fibroblast cell line: transformation induced by diverse oncogenes and cell death resulting from infection by avian leukosis viruses. Virology 248:295-304.

Hudson, DF., Morrison, C., Ruchaud, S. and Earnshaw, WC. 2002. Reverse genetics of essential genes in tissue-culture cells: 'dead cells talking’. Trends Cell Biol 12:281-287.

Jang, JH. 2005. Reciprocal relationship in gene expression between FGFR1 and FGFR3: implication for tumorigenesis. Oncogene 24:945-948.

Jaye, M., Schlessinger, J. and Dionne, CA. 1992. Fibroblast Growth-Factor Receptor Tyrosine Kinases - Molecular Analysis and Signal Transduction. Biochimica Et Biophysica Acta 1135: 185-199.

Johnson, M., Phua, HH., Bennett, SC., Spence, JM. and Farr, CJ. 2009. Studying vertebrate topoisomerase 2 function using a conditional knockdown system in DT40 cells. Nucleic Acids Research 37: -

Jung, JS., Kim, DK., Park, TS., Lee, SD., Lim, JM. and Han, JY. 2005. Development of novel markers for the characterization of chicken primordial germ. cells. Stem Cells 23:689-698.

Lee, BR., Kim, H., Park, TS., Moon, S., Cho, S., Park, T., Lim, JM. and Han, JY. 2007. A set of stage-specific gene transcripts identified in EK stage $\mathrm{X}$ and $\mathrm{HH}$ stage 3 chick embryos. BMC Dev Biol 7:60.

Lee, SI., Kim, JK., Park, HJ., Jang, HJ., Lee, HC., Min, T., Song, G. and Han, JY. 2010. Molecular Cloning and Characterization of the Germ Cell-Related Nuclear Orphan Receptor in Chickens. Molecular Reproduction and Development 77:273284.

Lee, SI., Lee, WK., Shin, JH., Han, BK., Moon, S., Cho, S., Park, T., Kim, H. and Han, JY. 2009. Sexually dimorphic gene expression in the chick brain before gonadal differentiation. Poultry Sci 88:1003-1015.

Livak, KJ. and Schmittgen, TD. 2001. Analysis of relative gene expression data using real-time quantitative PCR and the 2(T)(-Delta Delta C) method. Methods 25:402-408.

Ornitz, DM. and Itoh, N. 2001. Fibroblast growth factors. Genome Biol 2: -

Park, TS. and Han, JY. 2000. Derivation and characterization of pluripotent embryonic germ cells in chicken. Molecular Reproduction and Development 56:475-482.

Penaultllorca, F., Bertucci, F., Adelaide, J., Parc, P., Coulier, F., Jacquemier, J., Birnbaum, D. and Delapeyriere, O. 1995. Expression of Fgf and Fgf Receptor Genes in Human Breast-Cancer. International Journal of Cancer 61:170-176.

Tomlinson, DC., Lamont, FR., Shnyder, SD. and Knowles, MA. 2009. Fibroblast growth factor receptor 1 promotes proliferation and survival via activation of the mitogen-activated protein kinase pathway in bladder cancer. Cancer Res 69:4613-4620.

Yamaguchi, F., Saya, H., Bruner, JM. and Morrison, RS. 1994. Differential expression of two fibroblast growth factor-receptor genes is associated with malignant progression in human astrocytomas. Proc Natl Acad Sci U S A 91:484-488.

Yayon, A., Ma, YS., Safran, M., Klagsbrun, M. and Halaban, R 1997. Suppression of autocrine cell proliferation and tumorigenesis of human melanoma cells and fibroblast growth factor transformed fibroblasts by a kinase-deficient FGF receptor 1: evidence for the involvement of Src-family kinases. Oncogene 14:2999-3009.

(Received Nov. 10, 2010; Revised Dec. 20, 2010; Accepted Dec. 23, 2010) 